\title{
Comparison of Interpreting Teachers' Use and Perceptions of Distance Interpreter Training (DIT) Before and After the COVID-19 Pandemic: An Interview-Based Study
}

\author{
Mianjun Xu \\ (D)/0000-0003-1805-3103 \\ Guangdong University of Foreign Studies, China \\ Tianyuan Zhao \\ (D)/0000-0002-7104-6394 \\ Beijing Foreign Studies University, China

$$
\begin{aligned}
& \text { Juntao Deng } \\
& \text { (D)/0000-0002-3781-8952 }
\end{aligned}
$$ \\ Wuhan Institute of Technology, China \\ DOI: $h t t p s: / / d x . d o i . o r g / 10.46679 / 978819484830107$
}

Abstract

The study indicates that before the COVID-19 pandemic, despite its importance, distance interpreter training (DIT) was not positively perceived or widely used in higher education institutions that offer Bachelor of Translation and Interpreting (BTI) and/or Master of Translation and Interpreting (MTI) programs in China. However, the pandemic has changed almost everything in the world, with no exception of DIT, prompting the authors to have a follow-up study in August 2020 of the same 14 full-time interpreting teachers from different BTI and MTI institutions in different parts of China who had been interviewed right before the pandemic. This interview-based comparative study shows that all the interviewees used DIT during the pandemic shutdown and their perceptions of DIT have altered greatly, 
becoming more objective than subjective and more positive than negative. The pandemic has, to some extent, boosted the further development and acceptance of both the online and blended approaches to interpreter training.

Keywords: COVID-19; distance interpreter training (DIT); interpreting teachers; use and perceptions of DIT

\section{Introduction}

Professional interpreter training or interpreting education in China is mainly carried out in regular higher education institutions (HEIs) which have been approved the right to run Bachelor of Translation and Interpreting (BTI) and/or Master of Translation and Interpreting (MTI) programs, which were initiated in 2006 and 2007 respectively. As of 2020, there were 281 and 253 universities and colleges offering BTI and MTI programs respectively (for convenience's sake, they will be referred to as BTI and MTI institutions). These institutions include almost all types of universities and colleges, with different histories and divergent education resources, affecting either positively or negatively the quality of their BTI and MTI education (Xu, Zhao \& Zhong, 2020).

In order to share high-quality education resources among all HEIs, bridge inter-collegial and interregional disparities, and boost education equity, the Ministry of Education and other education authorities in China have encouraged the development of various distance education modes, such as Massive Open Online Courses (MOOCs), Small Private Online Courses (SPOCs), flipped classrooms, micro-lectures, and live webcast courses, because distance education has a number of advantages over traditional face-to-face instructions, such as accessibility at any time and space, large class capacity, repeatability of courses, and cost-effectiveness (Nguyen, 2015).

Among the different distance or online education modes in 


\section{This is a limited preview of the chapter.}

To read the full-text chapter, get access by purchasing this chapter or consider buying the complete book. If your library has subscription to EBSCOhost, the chapter including other chapters of the book can be accessed through your library.

This chapter is a part of the book, 'Contemporary Translation Studies' ISBN (paperback): 978-81-948483-0-1; ISBN (ebook): 978-81-948483-8-7

Book DOI: https://dx.doi.org/10.46679/9788194848301 
Fourth, studies on DIT in normal situations and in emergency cases should be strengthened so that its characteristics, advantages and disadvantages, coping tactics and the like are better known to individual teachers and education institutions to shift from offline to online or to the online and offline blended mode in the future.

This study, though small-scaled, has tried to compare interpreting teachers' use and perceptions of DIT right before and during the COVID-19 pandemic with follow-up interviews. Its significance lies in two aspects. First, it serves as a window to showcase the changes and development in DIT brought about by the pandemic. Second, it fills the lacuna of comparative studies of DIT from the perspective of interpreting teachers in China. It is hoped that this study can help draw more scholarly attention to DIT in particular and interpreting education in general.

\section{References}

Bao, W. 2020. COVID-19 and online teaching in higher education: A case study of Peking University. Hum Behav \& Emerg Tech (2), 113-115.

Carr, S., \& Steyn, D. G. 2000. Distance education training for interpreters--An insurmountable oxymoron? In: R. P. Roberts et al. (Eds.), The Critical Link 2: Interpreters in the Community (pp. 83-88). Amsterdam: John Benjamins.

Chan, C. H. 2013. From self-interpreting to real interpreting: A new web-based exercise to launch effective interpreting training. Perspectives, 21(3), 358-377. doi:10.1080/0907676X.2012.657654.

Chan, C. H. 2014. Building an online library for interpretation training: Explorations into an effective blended-learning mode. Computer Assisted Language Learning, 27(5), 454-479. doi:10.1080/09588221.2013.770034.

Chen, T., Peng, L., Yin, X., Rong, J., Yang, J., \& Cong, G. 2020. Analysis of user-satisfaction with online education platforms in China during the COVID-19 pandemic. Healthcare 8(200), 1-26. 
doi:10.3390/healthcare8030200.

Dong, P., Cheng, C., \& Zhao, F. 董鹏, 程传银, 赵富学. 2020. 新型冠状 病毒肺炎疫情下学校体育的价值、使命与担当[The values, missions and responsibilities of school sports education during the epidemic of COVID-19].体育学研究[Journal of Sports Research], 34 (2), 59-64.

Donitsa-Schmidt, S., \& Ramot, R. 2020. Opportunities and challenges: Teacher education in Israel in the COVID-19 pandemic. Journal of Education for Teaching. doi:10.1080/02607476.2020.1799708

$\mathrm{Fu}$, W., \& Zhou, H. 付卫东, 周洪宇. 2020. 新冠肺炎疫情给我国在线教 育带来的挑战及应对策略 [Challenges brought by 2019-nCoV epidemic to online education in China and coping strategies]. 河北师范大学学报(教育科学版) [Journal of Hebei Normal University (Educational Science)], (2), 14-18.

Kayalar, F. 2020. Shift to digitalized education due to COVID-19 pandemic and the difficulties the teachers encountered in the process. Proceedings of IAC 2020 in Venice.

Ko, L. 2006. Teaching interpreting by distance mode: Possibilities and constraints. Interpreting. International Journal of Research and Practice in Interpreting, 8(1), 67-96.

Ko, L. 2008. Teaching interpreting by distance mode: An empirical study. Meta, 53(4), 814-840.

Ko, L., \& Chen, N. S. 2011. Online-interpreting in synchronous cyber classrooms. Babel. Revue Internationale de la Traduction / International Journal of Translation, 57(2), 123-143. doi:10.1075/babel.57.2.01ko.

Lee, J., \& Huh, J. 2018. Why not go online?: A case study of blended mode business interpreting and translation certificate program. The Interpreter and Translator Trainer. doi:10.1080/1750399X.2018.1540227.

Kumar, M. J. 2020. COVID-19: How institutions, teachers and students in India have geared up for online education. IETE Technical Review 
37(3), 221-222.

Li, Q., Miao, Y., Zeng, X., Tarimo, C. S., Wu, C., \& Wu, J. 2020. Prevalence and factors for anxiety during the coronavirus disease 2019 (COVID-19) epidemic among the teachers in China, Journal of Affective Disorders doi:https://doi.org/10.1016/j.jad.2020.08.017

Li, Y., Rao, G., Zhang, J., \& Li, J. 2020. Conceptualizing national emergency language competence. Multilingua 39(5), 617-623.

Mayor, M. J. B., \& Ivars, A. J. 2007. E-learning for interpreting. Babel. Revue Internationale de la Traduction / International Journal of Translation, 53(4), 292-302.

Ministry of Education. 2019. China's MOOC construction going steadily and far. Available at http://www. moe.gov.cn/jyb_xwfb/xw_fbh/moe_2606/2019/ tqh20191031/sfcl/201910/t20191031_406249.html (accessed 8 February 2020).

Nguyen, T. 2015. The effectiveness of online learning: Beyond no significant difference and future horizons. MERLT Journal of Online Learning and Teaching 11(2), 309-319.

Qin, J. \& Xiang, Y. 覃军, 向云. 2020. 我国翻译在线开放课程现状及对 策研究——基于新冠肺炎疫情期间在线教学的反思[A study on the status quo and countermeasures of open online translation and interpreting courses in China: Based on reflections of online education during the COVID-19 pandemic]. 中国翻译[Chinese Translators Journal], 41(4), 67-75.

Quezada, R. L., Talbot, C., \& Quezada-Parker, K. B. 2020. From bricks and mortar to remote teaching: A teacher education programme's response to COVID-19. Journal of Education for Teaching. doi: $10.1080 / 02607476.2020 .1801330$

Şahin, M. 2013. Virtual worlds in interpreter training. The Interpreter and Translator Trainer, 7(1), 91-106. doi:10.1080/13556509.2013.798845.

Sandrelli, A. 2015. Becoming an interpreter: The role of computer 
technology. MonthTI, Special Issue, 2, 111-138. doi:

10.6035/MonTI.2015.ne2.4

Wang, D., Wang, H., Zhang, W., Wang, H., \& Shen, X. 王冬冬, 王怀波, 张伟，王海荣，沈晓萍. 2020. “停课不停学”时期的在线教学研 究-一基于全国范围内的 33240 份网络问卷调研[Research on online teaching in the period of "suspending classes without stopping learning"-Based on 33,240 online surveys across the country].现代教育技术[Modern Educational Technology], 30(3), 12-18.

Xu, M., Zhao, T., \& Zhong, W. 2020. On translator training in industry-specific universities in China-A case study of 16 MTI programs Lebende Sprachen.

Xu, M., Deng, J., \& Zhao, T. 2020. On status quo, problems, and future development of translation and interpreting MOOCs in China-A mixed methods approach. Journal of Interactive Media in Education (1), 13, 1-10. doi: https://doi.org/10.5334/jime.551

$\mathrm{Xu}, \mathrm{M}$, Zhao, T., \& Deng, J. 2021. An empirical study on distance interpreter training in China before the COVID-19 pandemic-A mixed methods approach. In Caiwen Wang \& Binghan Zheng (Eds.), Empirical Studies of Translation and Interpreting: The Post-Structuralist Approach. Routledge.

Zhai, S., Jiao, N., Yan, Y., \& Gu, X. 翟双庆，焦楠，间永红，谷晓红. 2020. 疫情“大考”背景下对中医药高等教育的思考[Reflections on higher education of Traditional Chinese Medicine under the background of epidemic situation].中国高教研究[China Higher Education Research], (4), 28-32.

Zheng, X. 郑璇. 2020a.加快推进中国手语翻译的职业化-一基于新型冠 状病毒肺炎疫情的思考[Promoting the professionalization of Chinese sign language interpretation: Reflections on the epidemic situation of COVID-19].残疾人研究[Disability Research], (1), 24-32.

Zheng, X. 郑璇. 2020b. 新冠肺炎疫情下听障人群语言应急服务的思考 
[Reflections on language emergency services for people with hearing loss in epidemic of COVID-19]. 语言战略研究[Chinese Journal of Language Policy and Planning], 5(3), 40-49.

\section{Appendix: Interview questions}

1. How long have you been teaching interpreting?

2. What interpreting course(s) have you taught?

3. What kinds of course(s) do you think are suitable for DIT?

4. Have you been engaged in any form of DIT? If yes, what are they?

5. Compared with traditional offline teaching, what do you think are the advantages and disadvantages of DIT?

6. What kinds of knowledge and competences are suitable for DIT?

7. Have you ever used any domestic and international online teaching resources in your interpreting teaching process? If yes, what are they?

8. Have you heard of any domestic or international online course management systems? If yes, what are they?

9. Have you used any online course management systems? If yes, what are they?

10. If you are engaged in DIT, what forms will you adopt?

11. What kind of DIT do you think the most effective?

12. How do you comment on existing domestic and international DIT resources?

13. Will you be willing to engage in DIT? What factors will boost or prevent you from doing so?

14. How do you predict the future development of DIT?

*15. How are you going to answer the above questions after your online education experience during the COVID-19 pandemic?

*16. What do you think are the reasons for such changes and how will they impact future interpreting education? 


\section{About the authors}

Mianjun $\mathrm{Xu}$ is an associate professor at Faculty of English Language and Culture / School of Interpreting and Translation Studies /Centre for Translation Studies, Guangdong University of Foreign Studies, Guangdong, People's Republic of China. She holds a PhD in translation and interpreting studies. Her research interests include translation and interpreting education and intercultural writings and she has published a dozen of academic papers in Chinese and international journals. Email address: mianjunxu@263.net)

Tianyuan Zhao is currently a post-doctoral researcher and lecturer at the Graduate School of Translation and Interpreting, Beijing Foreign Studies University, Beijing, People's Republic of China. Her research interests include interpreting studies and translation education and she has published several academic papers in core chinese and international journals. Email address: zhao910823@126.com

Juntao Deng is an associate professor in translation studies at the School of Foreign Languages, Wuhan Institute of Technology; and was a post-doctoral researcher at Guangdong University of Foreign Studies. His research interests are computer-assisted interpreter training and he has published a dozen of academic papers in Chinese and international journals. Email address: duncanenglish@126.com

\section{Acknowledgements}

This paper is part of the achievements of Hubei Provincial Higher Education Teaching Research Project "Design and Application of Co-constructive and Sharing Intelligent Speech Repository for Interpreter Training"(2018329); Scientific Research Project of Wuhan Institute of Technology "Research on the Deep Fusion Mechanism of Interpreter Education Informatization" (K201925); 2019 Guangdong Provincial Higher Education Teaching Reform Project "Research on 
Innovation and Entrepreneurship Education of Translators and Interpreters for the Medical and Technological Fields"; and Guangzhou Municipal Higher Education Innovation and Entrepreneurship Education Project (Curriculum and Teaching Research Project) "Research on Curriculum System of Cultural Entrepreneurship of Translation of Chinese Network Literature into Other Languages" and the Teaching Team of Series Translation Courses of Guangdong University of Foreign Studies, designated by Department of Education of Guangdong Province in 2020. 